\title{
Bioerosion of the coralline alga Hydrolithon onkodes by microborers in the coral reefs of Moorea, French Polynesia
}

\author{
Aline TRIBOLLET ${ }^{\mathrm{a} *}$, Claude PAYRI ${ }^{\mathrm{b}}$ \\ ${ }^{a}$ Centre d'océanologie de Marseille, UMR CNRS 6540, université de la Méditerranée, Station marine \\ d'Endoume, rue de la Batterie-des-Lions, 13007 Marseille, France \\ b Université de la Polynésie française, BP 6570 Faaa, Tahiti, Polynésie française
}

Received 24 January 2001; revised 15 May 2001; accepted 19 May 2001

\begin{abstract}
Calcareous skeletons of the coralline alga Hydrolithon onkodes are colonised by a variety of microboring organisms including euendolithic algae. The species composition of microboring organisms as well as the boring patterns and the boring activity differ between live and dead coralline crusts. The microborers inhabiting the live crusts form an obvious, macroscopically visible green layer in the basal part of the crust, which is in contact with the substratum underneath. Some species, primarily Plectonema terebrans $(83 \%)$ and Ostreobium quekettii $(7 \%)$ grow from the inside towards the crust's surface and produce a dense network of branched filaments. Following the death of the coralline alga, the skeletons are colonised at the surface and bored inward by the cyanobacteria Hyella caespitosa, Mastigocoleus testarum, P. terebrans and various chlorophyta. The bioerosive activity was determined using Image Analysis. Carbonate removal was estimated at $0.12 \mathrm{~g} \mathrm{CaCO}_{3} \cdot \mathrm{cm}^{-3}$ in the live crusts compared to 0.49 in dead crusts. Changes in endolith distribution and floristic composition between live and dead crusts, as well as subsequent changes in filament diameters of the microboring algal communities and penetration depth of endoliths, could explain the significantly higher rate of bioerosion in dead crust versus live crust. Endolith activity was found to vary between live and dead crusts; while microborers are direct agents of bioerosion in both live and dead crusts by removing carbonate from the skeletons ( 8 to $32 \%$ of the substratum, in volume), they indirectly increased bioerosion rate in dead crusts since they are themselves exposed to grazing by fish, echinoderms and molluscs. () 2001 Ifremer/CNRS/IRD/Éditions scientifiques et médicales Elsevier SAS
\end{abstract}

Résumé - Bioérosion de l'algue corallinacée Hydrolithon onkodes par des microperforants dans les récifs coralliens de Moorea en Polynésie française. Sur les récifs de la Polynésie française, les squelettes calcaires de l'algue corallinacée Hydrolithon onkodes sont colonisés par des micro-algues perforantes, les euendolithes (ou endolithes). La composition spécifique de ces communautés de microperforants, leur modèle de bioérosion ainsi que leur activité bioérosive varient entre les croûtes vivantes et mortes de l'algue. Dans les croûtes vivantes, seule la partie basale en contact avec le substrat de fixation, est colonisée par les endolithes et essentiellement par Plectonema terebrans $(83 \%)$ et Ostreobium quekettii (7\%). Ces espèces croissent de bas en haut en direction de la surface et forment un réseau dense de filaments ramifiés, visible à l'œil nu (bande basale verte). Dans les croûtes mortes, la partie basale mais également la partie supérieure sont colonisées et bioérodées par les cyanobactéries Hyella caespitosa, Mastigocoleus testarum, P. terebrans, et quelques chlorophycées. La quantification de la bioérosion par une analyse d'images a mis en évidence des taux de bioérosion de $0,12 \mathrm{~g} \mathrm{CaCO}_{3} \cdot \mathrm{cm}^{-3}$ pour l'algue vivante et de $0,49 \mathrm{~g} \mathrm{CaCO}_{3} \cdot \mathrm{cm}^{-3}$ pour l'algue morte. Cette

*Correspondence and reprints: fax: +33491041635.

E-mail address: tribollet@com.univ-mrs.fr (A. TRIBOLLET).

(C) 2001 Ifremer/CNRS/IRD/Éditions scientifiques et médicales Elsevier SAS. Tous droits réservés

S0399178401011501/FLA 
différence peut s'expliquer par les modifications de la composition spécifique, de la distribution, de la profondeur de pénétration et des diamètres des filaments endolithiques, après la mort de l'algue. Les quantités de $\mathrm{CaCO}_{3}$ bioérodées par dissolution par les euendolithes ne sont donc pas négligeables ( $8 \%$ du volume de la croûte vivante et $32 \%$ du volume de la croûte morte). Le rôle de la micro-flore perforante dans la bioérosion des substrats morts est d'autant plus important que cette micro-flore représente une importante source de nourriture pour les brouteurs érodeurs (poissons, mollusques, échinodermes). (c) 2001 Ifremer/CNRS/IRD/Éditions scientifiques et médicales Elsevier SAS

\section{bioerosion / coral reefs / coralline algae / endoliths / French Polynesia}

\section{bioérosion / récifs coralliens / algues corallinacées / endolithes / Polynésie française}

\section{INTRODUCTION}

The persistence of coral reefs results from a delicate balance between construction and erosion. Corals and calcareous algae contribute to reef building via biomineralisation, while macroborers (e.g. sponges, bivalves, polychaetes), microborers (cyanobacteria, algae, fungi, micro-invertebrates) and grazers (molluscs, echinoderms and parrot fishes) are the dominant agents of carbonate removal. This latter activity defined as bioerosion $\mathrm{New}$ mann.1966) has a sedimentological significance with regards to the production of bioclastic sediments Schneider and Torunski, 1983.

The widespread coral mortality Wilkinson.2000 combined with diseases of coralline algae $L$ Littler and Littler 1995) open new surfaces for bioerosion. Bioerosion rates are also higher on dead than on live substrata Pevrot Clausade et al. 1992; Le Campion-Alsumard et al. 1995a). The interaction between microborers and grazers may result in a change in microtopography Schneided and Torunski. 1983 and disrupt the construction/erosion equilibrium of the coral reef ecosystem.

Most studies on coral reef bioerosion have focused on skeletons of live and dead corals and various substrata including experimental blocks of dead corals (produced from live colonies) and shell fragments (Hutchings, 1986. Sammarco and Risk 1990: Hook and Golubic 1993. Kiene and Hutchings, 1994; Chazottes et al. 1995: Peyrot-Clausade et al. 1995; Mao Che et al. 1996; Par i et_al__1998) In contrast, calcareous encrusting red algae (Corallinaceae), the second most important biological and geological component in tropical coral reef ecosystems Steneck. 1986) have received far less attention.

Coralline algae can represent up to $90 \%$ of the living coverage of the outer reef flat in the atolls of French
Polynesia. They contribute significantly to the development and the structure of the reef either as framebuilders, or organisms cementing coarse- and finegrained carbonate deposits (Borowitzka, 1983; Payri, 1995: Adey, 1998) Recent studies have documented the external bioerosion of encrusting coralline algae by rasping and grazing organisms, e.g. gastropods, echinoderms and scarid fish Bellwood, 1995; Bruggemann et al 1996). Conversely, the internal bioerosion by microborers and macroborers has received less attention (see Steneck, 1986 for a review). In tropical coralline skeletons, the presence of boring micro-organisms was first reported by Weher van Bosse (1932) who described a diverse assemblage of endolithic micro-algae. Other studies dealing with boring endoliths have occasionally referred to calcareous algal substrata Le CampionAlsumard, 1979; Anagnostidis and Pantazidou, 1988). More recently, Ghirardelli and Prats (1996) and Ghirardelli_(1998) have reported that in the northern Adriatic sea the endolithic cyanobacterium Plectonema terebrans lives in the cell wall of live specimens of several Corallinaceae, including Hydrolithon. The contribution of endolithic organisms to bioerosion has been suggested to be less important than grazing activity Hutchings, 1986; Chazottes et al. 1995). However, regardless of the direct contribution of these microorganisms to bioerosion, they stimulate the bioerosion process by providing a renewable food source for grazers and by allowing the colonization of the altered substrata by macroborers Golubic and Schneider 1979. Schneider and Torunski. 1983; Bellwood and Choat, 1990).

In French Polynesia, bioerosion processes have been investigated mainly on Tiahura reef, Moorea Island, on various carbonate substrata (Peyrot-Clausade et al 1992, 1995; Chazottes et al., 1995; Le Campion- Al- 
sumard et al. 1995a, 1995b; Pari et al_ 1998) To complement these results, the present paper focuses on microborer erosion within the skeleton of Hydrolithon onkodes, the most common coralline alga found on the reefs of French Polynesia. Our objectives were to characterise the endolithic communities present in live and dead crusts of $H$. onkodes, to quantify their boring activity and to ascertain their significance in bioerosional processes.

\section{MATERIALS AND METHODS}

\subsection{Study area}

Samples were collected on the Tiahura outer reef located on the north-western side of Moorea Island, French Polynesia (17 $30^{\prime} \mathrm{S}, 149^{\circ} 50^{\prime} \mathrm{W}$ ) (foure -1 ). The reefs in this area are well-documented Galzin and Pointier, 1985. Augustin et al 1997 with respect to calcification (Gat uso et al. 1993: Payri. 1995) and bioerosion (Peyrot Clausade et al. 1992, 1995; Chazottes et al. 1995; Ld Campion-Alsumard et al. 1995a, 1995b; Pari et al. 1998.

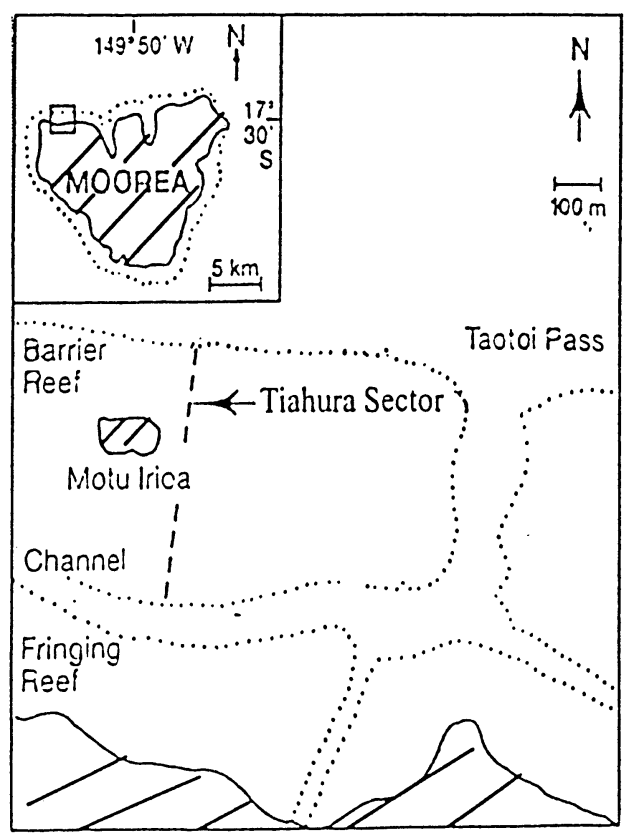

Figure 1. Study site on the NW coast of the high volcanic island of Moorea (inset), near Tahiti, French Polynesia. Modified from Gattusd et_al_(1993).

\subsection{Sampling design and analytical procedures}

Hydrolithon onkodes (Heydrich) Penrose and Woelkerling (1992) covers $4 \%$ of the Tiahura outer reef. Endolithic organisms were studied in live and dead crusts of the coralline alga. Crusts were randomly collected in March 1998, on dead corals in shallow water (about $1 \mathrm{~m}$ depth) with a hammer and a chisel. Nine small fragments of both live and dead algal skeletons $(2 \times 2 \times 0.5 \mathrm{~cm})$ with associated endoliths were fixed in a buffered $5 \%$ solution of formaldehyde in seawater or in Johansen's solution $(100 \mathrm{~mL}$ seawater, $1 \mathrm{~mL}$ acetic acid and $1 \mathrm{~g}$ chromic acid), which started the dissolution.

Two different sets of live and dead crusts were randomly selected. Three live crusts and three dead crusts composed the first set. The second set included two live crusts and one dead crust.

To understand the role of these boring micro-organisms in $H$. onkodes alga, several variables were investigated:

- the specific composition of the endolithic communities were identified and characterised by determining the filaments, as well as their diameters and their densities; - the rates of bioerosion were estimated using endolithic depths of penetration, the dimensions of the crusts (or sections of crusts) and the bored surface areas.

As endoliths live in and actively bore into the carbonate skeleton, we applied the following methods to directly measure in the crust different variables required to estimate the rate of bioerosion.

\subsubsection{Species identification, filament diameters and densities}

The following procedure was implemented in order to identify and characterise the boring microflora communities in the live and dead crusts of Hydrolithon onkodes.

Samples from the first set (three fragments of live crusts and three fragments of dead crusts) were prepared by dissolving the crustose coralline alga with Perenyi's solution ( 3 vol. $0.5 \%$ chromic acid, 4 vol. $10 \%$ nitric acid, 3 vol. $90 \%$ ethanol).

The extracted endoliths were mounted on glass slides for microscopic study, using Leitz Orthoplan microscope, with a $40 \times$ objective power. The taxonomic identifications were done according to Le Campion-Alsumard 1979) and Le Campion-Alsumard et al. (1995a) 


\title{
Section of a live crust (sample 1)
}

\author{
Section of a dead crust
}
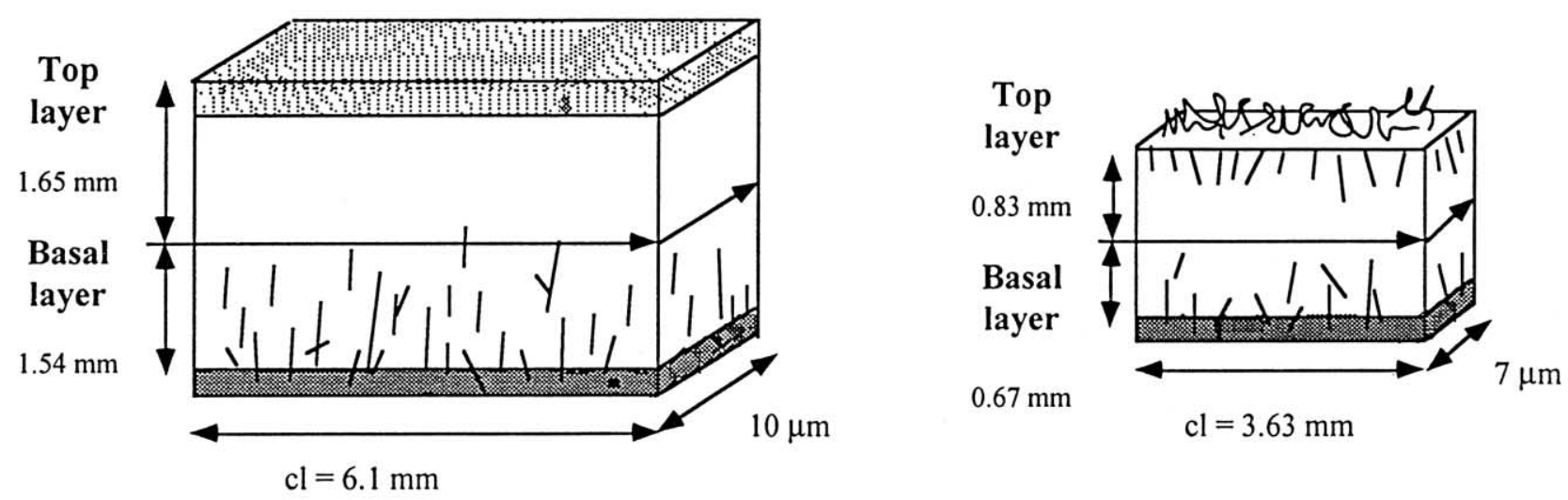

pigmented cells Dead coral substrate

If Epiliths

IV Endoliths

Figure 2. Diagram of microbial endolith bands on sections of live and dead crusts of Hydrolithon onkodes.

This identification was completed by observations of resin casts using scanning electronic microscopy according to the Golubic et al a (1970) method.

Filament diameters (mean in $\mu \mathrm{m}$ ) were estimated from 100 filaments per endolithic species using a drawing tube calibrated using an object micrometer slide and associated with the light microscope. The filament densities for each species (in percent) were estimated in three 1.86$\mathrm{mm}^{2}$ round optical fields per sample.

\subsubsection{Estimation of bioerosion}

\subsubsection{Sample preparation}

Samples of the second set (two live crusts and one dead crust) fixed in Johansen's solution, were decalcified using Perenyi's solution, rinsed with seawater and deionised water and finally dehydrated in a graded butanol series.

Prior to embedding in paraffin, tissues with endoliths were transferred into a mixture of butanol and melted paraffin wax (1:1) for $2 \mathrm{~h}$. Sections perpendicular to the algal surface were cut. Their thickness ranged from $7 \mu \mathrm{m}$ in the dead crust to $10 \mu \mathrm{m}$ for the live crusts (fgure 2).
They were stained with aqueous $5 \%$ toluidine blue for $10 \mathrm{~s}$ after removal of the paraffin in several changes of toluene for $3 \mathrm{~min}$ and rehydration in a graded ethanol water series for 3-5 min. Sections were mounted on glass microscope slides (six to eight per slide) using Eukitt embedding resin and covered with a cover-glass after dehydration in a graded ethanol series and three changes of toluene for $3 \mathrm{~min}$.

The light microscopic examination of sections has shown that endoliths formed dense coloured layers within the coralline. A basal layer is prominent in both live and dead crusts. An additional top layer developed in dead crusts close to the crust surface (figure 2).

\subsubsection{Bioerosion rate}

In order to estimate the bioerosion rates, randomly selected sections were examined using a Leica DMLB stereo-microscope equipped with a digital CCD camera and Visilog 4.1, image-processing software.

First, the loss of $\mathrm{CaCO}_{3}$ due to boring activity was estimated by measuring bored surfaces on prepared sections of live and dead coralline crusts. Image analysis 
was applied to quadrats as sampling area units randomly selected along each bored layer. Quadrat sizes were determined by the Wiegert (1962) method. The surface area examined was $0.0123 \mathrm{~mm}^{2}$ for the top and basal layers of the dead crust, and $0.037 \mathrm{~mm}^{2}$ for the basal layer in live crusts. The bored surfaces were expressed in $\mathrm{mm}^{2}$ after a calibration of the $x$-scale and $y$-scale of the images $\left(1\right.$ pixel $\left.=4.69 \mu \mathrm{m}^{2}\right)$ provided by the Visilog 4.1 software.

Second, the mean of the bored surface areas per layer ( $b a$ in $\mathrm{mm}^{2}$ ) was obtained with:

$b a=q b a \times a / q a$

where $q b a$ is the mean of the quadrat bored surface areas, $a$ the mean of each layer surface areas, and $q a$ the quadrat surface area.

The mean of each layer surface areas $(a)$ was obtained with:

$a=e z \times c l$

where $e z$ is the mean of the penetration depths by endoliths and $\mathrm{cl}$ the mean of the crust lengths.

The mean of the bioerosion rate $\left(B r_{1}\right.$, in $\left.\%\right)$ for each layer was obtained by the ratio:

$B r_{1}=(b a / a) \times 100$.

For each microbored layer the rate of bioerosion $\left(\mathrm{Br}_{2}\right)$ expressed in $\mathrm{g} \cdot \mathrm{cm}^{-3}$ was obtained with:

$B r_{2}=B r_{1} \times 1.50$

where $1.50 \mathrm{~g} \cdot \mathrm{cm}^{-3}$ was the relative skeletal density of Hydrolithon (Payri. 1995).

The total bioerosion rates per crust in $\mathrm{g} \cdot \mathrm{cm}^{-3}$ were obtained by adding up the rates of each layer (top + basal).

\subsubsection{Statistical analysis}

The number of quadrats, sections and slides needed for a significant statistical calculation of the microbial bioerosion rates were determined using a three-way analysis of variance (ANOVA; crossed classification). The results are given in table.

A two-way ANOVA with equal replication (crossed classification) was performed on the 'filament diameter'
Table I. Number of slides, sections per slide and quadrats, determined by a three-way analysis of variance (CI $95 \% ; P>0.1$ for slides and sections; $P<0.001$ for the quadrats).

\begin{tabular}{|c|c|c|c|c|}
\hline & \multicolumn{2}{|c|}{ Live crusts } & \multicolumn{2}{|c|}{ Dead crusts } \\
\hline & $\begin{array}{l}\text { Basal } \\
\text { layer } \\
\text { (sample 1) }\end{array}$ & $\begin{array}{l}\text { Basal } \\
\text { layer } \\
\text { (sample 2) }\end{array}$ & $\begin{array}{l}\text { Top } \\
\text { layer }\end{array}$ & $\begin{array}{l}\text { Basal } \\
\text { layer }\end{array}$ \\
\hline Number of slides & 1 & 1 & 2 & 1 \\
\hline $\begin{array}{l}\text { Number of sections } \\
\text { per slide }\end{array}$ & 3 & 3 & 2 & 4 \\
\hline $\begin{array}{l}\text { Number of quadrats } \\
\text { per section }\end{array}$ & 5 & 13 & 30 & 7 \\
\hline $\begin{array}{l}\text { Total number of } \\
\text { quadrats }\end{array}$ & 15 & 39 & 120 & 28 \\
\hline
\end{tabular}

variable to investigate the effects of species and substrata (live and dead crusts). Multiple comparison of means according to Student-Newman-Keuls (SNK) test (Zar, 1984) were used to determine which of these means were significantly different from each other.

To investigate the differences between the bored layers (top and basal) of live and dead crusts, a non-parametric Mann-Whitney test (Dagnelie, 1970) was performed on the 'rate of bioerosion' variable, since the homoscedasticity condition was not met (Hartley test).

The coefficients of variation $(\mathrm{VC}=(\mathrm{SD} \times 100) /$ mean, where SD is the standard deviation) of the bioerosion rate for each crust were calculated to identify the potential heterogeneity of the boring micro-organism repartitions in the crusts (a high VC corresponding to a high hetereogeneity of the distribution).

For all the analyses the software SuperAnova 1.11 (1991) and Statview5 (1998) were used.

\section{RESULTS}

\subsection{Composition and distribution of the boring microflora}

Because of the dense matrix formed by the cells of the coralline thallus, endoliths could be observed directly in their original position. The endolithic microflora present in Hydrolithon onkodes crusts consisted of an assemblage of several species, principally the cyanobacteria Hyella 
Table II. Distribution of the different species of endoliths in live and dead crusts (0: absence; +: few filaments; ++: numerous filaments).

\begin{tabular}{|c|c|c|c|c|}
\hline \multirow[t]{2}{*}{ Species } & \multicolumn{2}{|c|}{$\begin{array}{l}\text { Live crusts of } \\
\text { H. onkodes }\end{array}$} & \multicolumn{2}{|c|}{$\begin{array}{l}\text { Dead crusts of } \\
\text { H. onkodes }\end{array}$} \\
\hline & $\begin{array}{l}\text { Top } \\
\text { layer }\end{array}$ & $\begin{array}{l}\text { Basal } \\
\text { layer }\end{array}$ & $\begin{array}{l}\text { Top } \\
\text { layer }\end{array}$ & $\begin{array}{l}\text { Basal } \\
\text { layer }\end{array}$ \\
\hline $\begin{array}{l}\text { Hyella caespitosa } \\
\text { (Bornet and Flahault, } \\
\text { 1889) }\end{array}$ & 0 & + & ++ & + \\
\hline $\begin{array}{l}\text { Mastigocoleus testarum } \\
\text { (Bornet and Flahault, } \\
\text { 1889) }\end{array}$ & 0 & + & ++ & + \\
\hline $\begin{array}{l}\text { Plectonema terebrans } \\
\text { (Bornet and Flahault, } \\
\text { 1889) }\end{array}$ & + & ++ & ++ & ++ \\
\hline $\begin{array}{l}\text { Ostreobium quekettii } \\
\text { (Bornet and Flahault, } \\
\text { 1889) }\end{array}$ & + & ++ & ++ & ++ \\
\hline $\begin{array}{l}\text { Unidentified chlorophyta } \\
\text { species }\end{array}$ & 0 & + & ++ & + \\
\hline
\end{tabular}

caespitosa, Plectonema terebrans and Mastigocoleus testarum (figure $3 a-d$ ), accompanied by the siphonalean chlorophyta Ostreobium quekettii (Goure $3 e$. A) and some unidentified chlorophyta species (table I

In living $H$. onkodes crusts, mostly $P$. terebrans and $O$. quekettii formed the obvious visible green layer. This layer is parallel to the surface and located in the lower part of the crusts in contact with the surface of the coral underneath (figure $4 a$ b ). Some filaments of these two species were occasionally observed in the top layer but originated from the lower part of the crust (table I d ).

When damaged, $H$. onkodes crusts loose their yellowpink colour and the surface of the thallus became white to grey following the death of the pigmented epithellial cells. During the weeks following death, the surface is overgrown by various epilithic species including cyanobacteria (figure 4 d), green and red algae. Dead portions of the crusts are colonised by micro-organisms, which penetrate the crust from the surface down into the thallus. In our samples, this top layer comprised the cyanobacteria: $M$. testarum, $H$. caespitosa and some undetermined chlorophyta (table $\mathrm{C}$ ). These species grow from the upper surface downward into the skeleton in the direction of the basal layer underneath (figure 4d).

This latter layer was similar to the basal layer encountered in live crusts with mostly $P$. terebrans and $O$. quekettii. Moreover, M. testarum and $H$. caespitosa filaments were located in the top green layer while very few filaments were observed in the basal layer. Only few filaments of fungi were observed in the top and basal layers (figure $4 d$ ) and some were associated with the $O$. quekettii filaments (Goure 3 d).

\subsection{Depth of penetration}

In the live crusts, the mean height of the basal layer varied from $1.03 \pm 0.09$ to $1.6 \pm 0.25 \mathrm{~mm}$ (table $\mathrm{Wl}$ ), which represented about half of the height crusts in the two studied samples (samples 1 and 2).

In the top layer of the dead crusts, endoliths from the surface down into the substratum were mainly restricted to the upper surface and then decreased rapidly with depth, reaching a mean penetration depth of $0.5 \pm 0.1 \mathrm{~mm}$.

The mean penetration depth of endoliths in the basal layer was $0.6 \pm 0.2 \mathrm{~mm}($ table $\mathrm{Ut})$. This layer had the same characteristics as the basal layer described in the live crusts.

Table III. Mean \pm standard deviation ( $\mathrm{mm}$ ) of crusts thickness, section dimensions and maximum depth of penetration by endoliths, in live and dead crusts of Hydrolithon onkodes.

\begin{tabular}{llcc}
\hline & $\begin{array}{l}\text { Live crust 'sample 1' } \\
(n=28)\end{array}$ & $\begin{array}{l}\text { Live crust 'sample 2' } \\
(n=24)\end{array}$ & $\begin{array}{l}\text { Dead crust } \\
(n=36)\end{array}$ \\
\hline Section length $(c l)$ & $6.10 \pm 0.03$ & $9.44 \pm 0.21$ & $3.63 \pm 0.29$ \\
Top layer height & $1.54 \pm 0.32$ & $1.01 \pm 0.07$ & $0.82 \pm 0.07$ \\
Basal layer height & $1.65 \pm 0.25$ & $1.03 \pm 0.09$ & $0.67 \pm 0.08$ \\
Total height & $3.19 \pm 0.29$ & $2.04 \pm 0.13$ & $1.49 \pm 0.11$ \\
Penetration depth in top layer $(e z)$ & - & $1.03 \pm 0.09$ & $0.50 \pm 0.10$ \\
Penetration depth in basal layer $(e z)$ & $1.60 \pm 0.25$ & $0.60 \pm 0.20$ \\
\hline
\end{tabular}



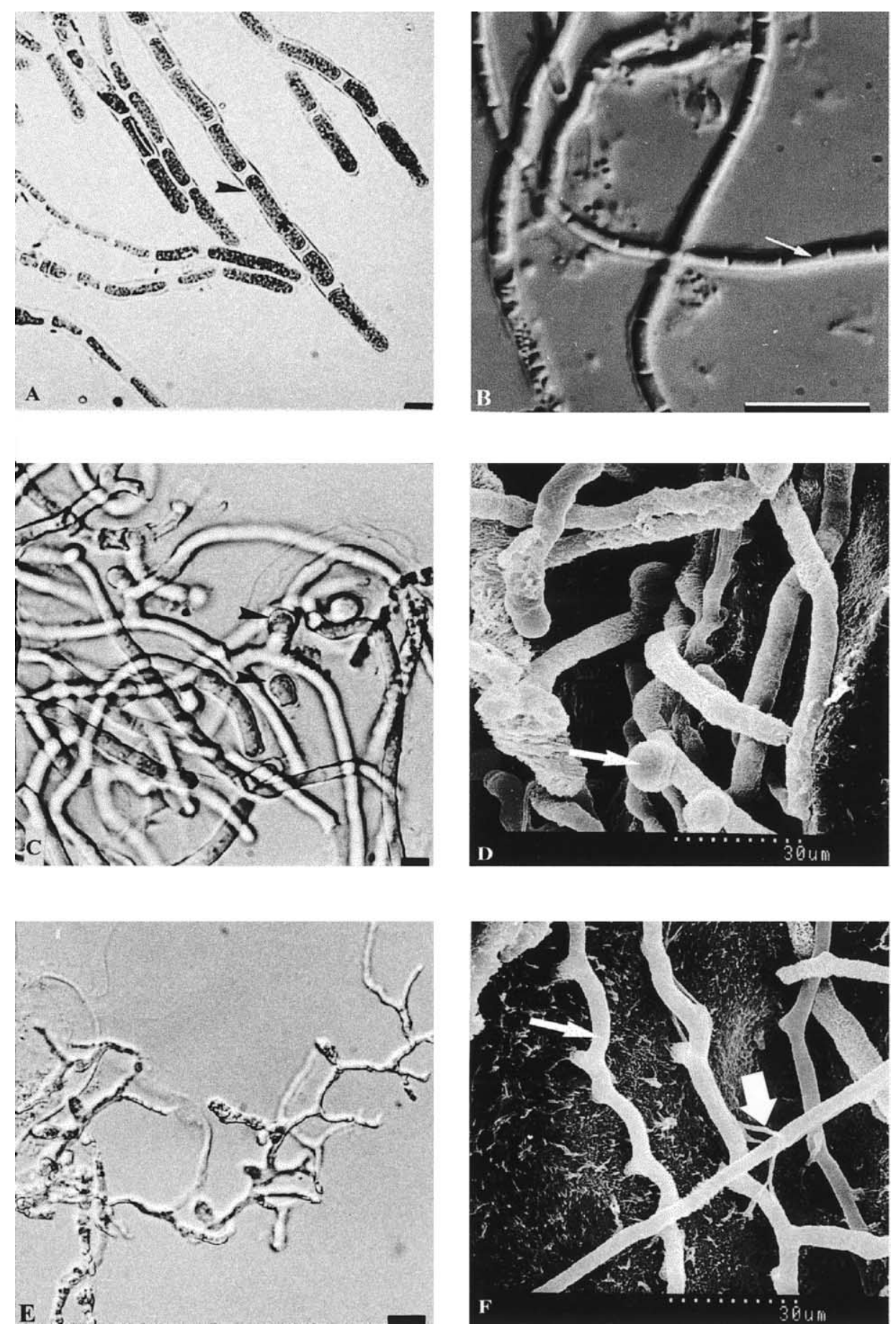

Figure 3. Endolithic micro-organisms in dead and live crusts of Hydrolithon onkodes. A. Filaments and cells (arrow) of the cyanobacterium Hyella caespitosa. B. Filaments and cells (arrow) of the cyanobacterium Plectonema terebrans. C. Filaments with heterocysts (arrow) of the cyanobacterium Mastigocoleus testarum. D. Resin casts of borings of M. testarum showing heterocyst (arrow) embedded in terminal position of short lateral branches. E. Filaments of the siphonalean chlorophyta Ostreobium quekettii. F. Resin casts of filamentous microborings of $O$. quekettii (fine arrow) and hyphae of parasitic fungi (bold arrow) as seen in etched petrographic section. A, B, C and $\mathbf{E}$ are light micrographs, $\mathbf{D}$ and $\mathbf{F}$ scanning electron micrographs. Scale bar is $10 \mu \mathrm{m}$ long unless otherwise indicated. 

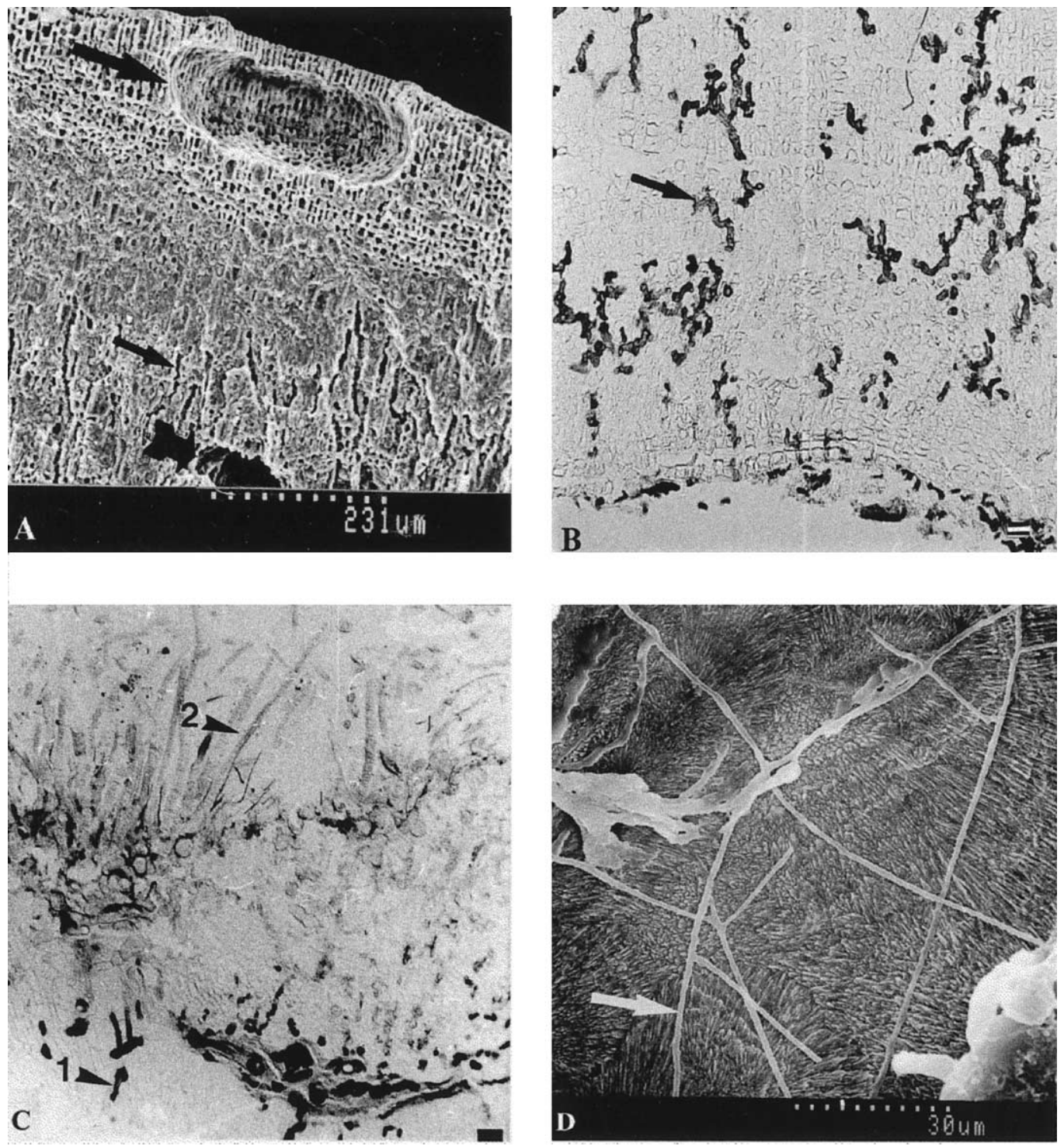

Figure 4. Microborings and endolithic filaments in live and dead crusts of Hydrolithon onkodes. A. Scanning electronic microscopy of a petrographic section of a live crust showing the live cells in the top layer without microborings but with the algal conceptacle (large arrow) and the bored basal layer (thin arrow). B. Light micrograph of a paraffin section showing the basal band of a live crust colonised by coloured endoliths (arrow) which originate from the underlying Porites substratum. C. Light micrograph of a paraffin section showing endolithic algae located in the apical band (arrow 1) and epilithic algae (arrow 2) in the exposed surface. D. Scanning electronic microscopy of a petrographic section showing the microborings of fungal filaments (arrow).

\subsection{Diameter and density of endolithic filaments}

The filament diameters and their densities for the different endolithic species are given in table ID and figure 5 The filament diameters were significantly different from one species to another (ANOVA, $P<0.0001$ and SNK test) and varied between substrata (live vs. dead). In fact, this result is mostly due to the filament diameter of the cyanobacterium Mastigocoleus testarum, which was significantly larger (SNK test) in the dead $(8.2 \pm 0.2 \mu \mathrm{m})$ than in the live $(7.3 \pm 0.2 \mu \mathrm{m})$ crusts. 
Table IV. Mean \pm standard deviation of filament diameters $(\mu \mathrm{m})$ in live and dead crusts of Hydrolithon onkodes. NA: not available.

\begin{tabular}{|c|c|c|}
\hline Species & $\begin{array}{l}\text { Live crusts } \\
\text { Filament diameters } \\
(n=100)\end{array}$ & $\begin{array}{l}\text { Dead crusts } \\
\text { Filament diameters } \\
(n=100)\end{array}$ \\
\hline O. quekettii & $4.3 \pm 0.8$ & $3.8 \pm 0.4$ \\
\hline M. testarum & $7.3 \pm 0.2$ & $8.2 \pm 0.2$ \\
\hline P. terebrans & $1.6 \pm 0.2$ & $1.7 \pm 0.3$ \\
\hline H. caespitosa & $5.1 \pm 0.6$ & $5.3 \pm 1.4$ \\
\hline $\begin{array}{l}\text { Unidentified chlorophyta } \\
\text { species }\end{array}$ & NA & NA \\
\hline
\end{tabular}

The filament diameters of unidentified chlorophyta species were so polymorphic in the live and dead crusts that they were not measured.

In the live crusts, Plectonema terebrans had the smallest mean diameter $(1.6 \pm 0.2 \mu \mathrm{m})$ but represented $83 \%$ of the microboring community. The mean filament diameter of Ostreobium queketti was of $4.3 \pm 0.8 \mu \mathrm{m}$ and this species represented $7 \%$ of the assemblage. The two other cyanobacteria M. testarum and Hyella caespitosa had the
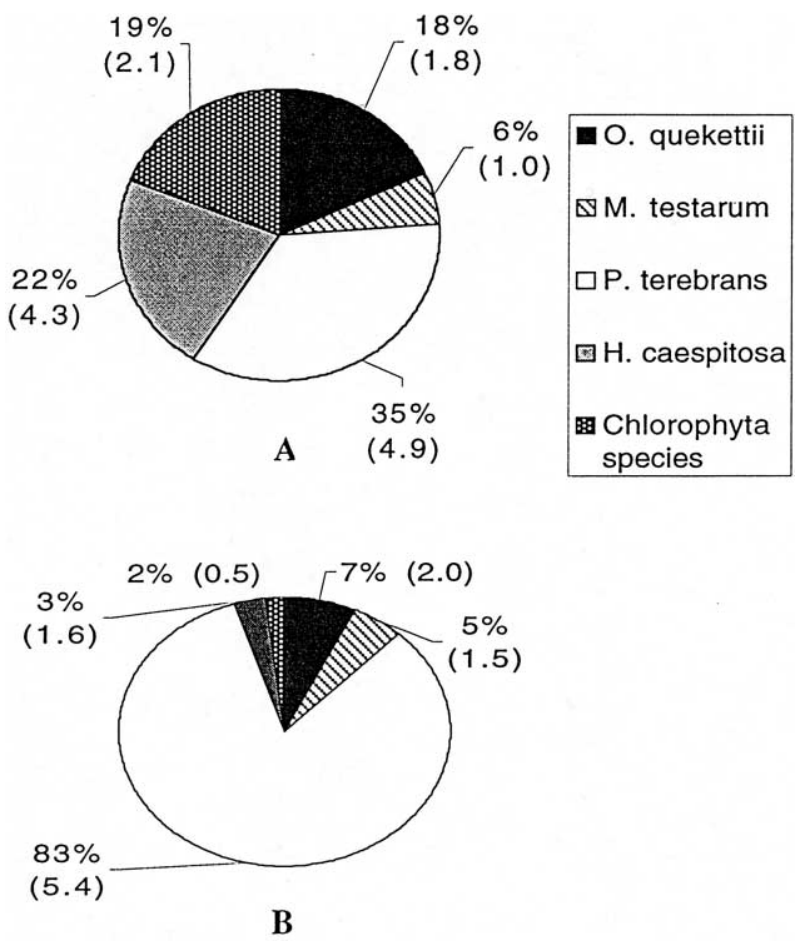

Figure 5. Densities (\%) of the endolithic filaments per species (mean and standard deviation) in dead (A) and (B) live crusts of H. onkodes. largest mean filament diameter and represented only a few percent of the micro-organisms in the basal layer. All these species, which have grown primarily perpendicular to the basal part of the crusts from the inside towards the surface, form a dense network of branched filaments.

In the dead crusts, P. terebrans filaments had also the smallest mean diameter $(1.7 \pm 0.3 \mu \mathrm{m})$ but represented only $35 \%$ of the community, representing a drop-off factor of 2.4 compared to live crusts. In contrast, the number of the $O$. queketti filaments increased with a factor of $2.6(18 \%)$ compared to live crust $(7 \%)$. The two other cyanobacteria $M$. testarum and $H$. caespitosa still had the largest mean filament diameter representing respectively 6 and $22 \%$, respectively, of the assemblage, most located in the top layer. The density of $H$. caespitosa filaments was seven times more abundant in the dead crusts than in the live crusts.

\subsection{Rates of microflora bioerosion}

The bioerosion rates in the basal layers of the live crusts were not significantly different from each other (nonparametric test of Mann-Whitney, $P=0.75$ ) and were pooled together. The subsequent mean bioerosion rate was estimated to be $0.12 \pm 0.07 \mathrm{~g} \cdot \mathrm{cm}^{-3}$ of $\mathrm{CaCO}_{3}$ removed in the live crust as the bioerosion rate is zero in the top layer, which represents $7.9 \pm 0.82 \%$ of bored substratum by endoliths. Details on the bioerosion rates for each live crust (samples 1 and 2) are given in table $\mathbf{Z}$.

In the top and basal layers of the dead Hydrolithon onkodes crust, the microborers occupied $28.9 \pm 32.2$ and $2.7 \pm 3.19 \%$ respectively of the skeletal volume table Ш). Subsequently, the total estimated bioerosion activity reached $0.49 \pm 0.54 \mathrm{~g} \cdot \mathrm{cm}^{-3}$ of $\mathrm{CaCO}_{3}$.

The bioerosion rate of the dead basal layer was significantly lower $(P<0.0001)$ than in the live crusts. The bioerosion rates of the top and basal layers of the dead crusts were significantly different $(P<0.024)(t a b l e-1)$.

The variation coefficients were calculated for the basal layer of the live crust and for the top and basal layers of the dead crust. They were $62.5,110.5$ and 114.5 , respectively. These coefficients reflect the heterogeneity of the endolith distribution in the crusts. The heterogeneity of the endolithic repartition was higher in the dead crust than in the live crust. 
Table V. Mean of the layer surfaces, mean of the bored surfaces per quadrat and per layer, percentage of bioerosion for each layer and rates of bioerosion per layer and per crust of live and dead H. onkodes.

\begin{tabular}{|c|c|c|c|c|}
\hline & \multicolumn{2}{|c|}{ Live crusts } & \multicolumn{2}{|c|}{ Dead crust } \\
\hline & $\begin{array}{l}\text { Basal layer } \\
\text { (sample 1) }\end{array}$ & $\begin{array}{l}\text { Basal layer } \\
\text { (sample 2) }\end{array}$ & Top layer & Basal layer \\
\hline Layer surface areas $\left(\mathrm{mm}^{2}\right)$ & $9.24 \pm 1.10$ & $9.43 \pm 0.72$ & $2.97 \pm 0.29$ & $2.41 \pm 0.34$ \\
\hline Bored surface area per quadrat $\left(\mathrm{mm}^{2}\right)$ & $0.0034 \pm 0.0029$ & $0.0027 \pm 0.0009$ & $0.0036 \pm 0.0039$ & $0.00033 \pm 0.0004$ \\
\hline Bored surface area per layer $\left(\mathrm{mm}^{2}\right)$ & $0.87 \pm 0.71$ & $0.68 \pm 0.23$ & $0.86 \pm 0.96$ & $0.07 \pm 0.08$ \\
\hline Bioerosion $(\%)$ & $9.36 \pm 7.72$ & $7.18 \pm 2.40$ & $28.90 \pm 32.20$ & $2.70 \pm 3.19$ \\
\hline Bioerosion rate per layer $\left(\mathrm{g} \cdot \mathrm{m}^{-3}\right)$ & $0.14 \pm 0.12$ & $0.11 \pm 0.04$ & $0.45 \pm 0.50$ & $0.04 \pm 0.04$ \\
\hline Bioerosion rate per crust $\left(\mathrm{g} \cdot \mathrm{cm}^{-3}\right)$ & $0.12 \pm 0.07$ & & $0.49 \pm 0.54$ & \\
\hline
\end{tabular}

\section{DISCUSSION}

\subsection{Microboring specific composition}

The microboring assemblages in live and dead crusts comprise species, which are euendoliths, i.e. filaments penetrating and residing within the carbonate skeleton Golubic et al 1981; Schneider and Le CampionAlsumard, 1999. However, the species composition as well as the boring patterns and the boring activity differs between live and dead crusts of Hydrolithon onkodes.

The present study establishes the abundant presence of euendolithic cyanobacteria and chlorophyta in the skeleton of $H$. onkodes.

In the dead crusts, the microboring community is characterised by a mixture of endolithic species while live crusts are dominated by the thinnest cyanobacterium Plectonema terebrans. These results contrast with those published by Kiene et al (1995) and Vogel et al (1996) who have described microborer communities in the Bahamas dominated by boring red algae Conchocelisphase and the green alga Ostreobium queckettii while $P$. terebrans was less abundant. Very few fungi were found in our study while they are frequently observed in association with boring algae in various other calcareous substrata Kendrick et al 1982: Le Campion-Alsumard et al. 1995h; Man Che et al, 1996; Vogel et al, 1996; Priess et al.,2000). However, the endolithic communities found within $H$. onkodes crusts remain similar to those described in various carbonate substrata, e.g. in blocks of coral (Chazottes et al. 1995) in live and dead corals $(\mathrm{L}$ Campion-Alsumard et al. 1995a and in mollusc shells (Mao Che et al. 1996) in French Polynesia.
The micro-organisms which dominate the intertidal euendolithic community in French Polynesia have been recorded throughout most of the tropical areas Radtke et al. 1997). However, slight differences in the specific composition of these micro-organisms were apparent between the Pacific and the Caribbean areas Gektidis. 1999] especially in regards to cyanobacteria and rhodophyta.

\subsection{Distribution of the microboring communities}

In the live crusts, euendoliths colonise only the lower part of the skeleton, which is in contact with the substratum. For most of our samples, the substratum was composed mostly of the coral Porites. It is likely that the infection originates from the dead coral skeleton underneath since the external live crust is never or hardly infected. Moreover, on the same site (Tiahura), the euendoliths developing in coral skeleton include the species as those found in the coralline substrata $\mathrm{Le}$ Campion-Alsumard et al. 1995a

It is likely that the euendoliths do not penetrate the live crusts from the surface because live cells prevent biofouling by sloughing of epithellial cells as described for many corallines Keats et al. 1993). A similar process occurs in live corals, where the tissue layers protect against colonisation by euendoliths Le CampionAlsumard et al., 1995a.

In the dead crusts, the top green layer corresponds to a post mortem colonisation by negatively phototropic taxa, e.g. the cyanobacteria Hyella caespitosa and Mastigocoleus testarum and some chlorophyta, which penetrate the crust from the surface down into the skeleton. The 
presence of these species in the top layer can be explained by light availability since they require more light than micro-algae such as the chlorophyta Ostreobium $\mathrm{Ld}$ Campion-Alsumard_ 1979). These species are widely observed in tropical environments within carbonate substrata such as dead mollusc shells, dead coral skeletons and reef limestone Golubic et al. 1981: Le Campion Alsumard. 1989; Mao Che et al. 1996; Zubia and Pevrot-Clausade.2001 and are considered as pioneers in the colonisation processes CChazottes et al. 1995: Le Campion-Alsumard et al. 1995a).

The live crusts and the basal layer of the dead crust are characterised by the presence of positively phototropic and oligophotic species like $O$. quekettii and Plectonema terebrans (Lukas, 1974). However, these two species were observed growing both upward and downward in the dead substrata. Moreover, Ostreobium is known as an ubiquitous endolith (Lukas, 1974).

Recently, Gektidis (1999) demonstrated that in the shallow waters of Lee Stocking Island (Bahamas), juvenile communities consist of cyanobacteria, chlorophyta and rhodophyta (CyChloRho-association). In contrast, the mature communities shift to an OstPleHet-association, which is characterised by $O$. quekettii, P. terebrans and heterotrophic microborers. Moreover, previous studies on coral bioerosion have shown a series of replacements of colonisers following the death and denudation of the coral, with an ultimate prevalence of species that are competitive under relatively stable, long-term conditions such as O. quekettii CChazottes et al. 1995: Le CampionAlsumard et al. 1995a). These results suggest that the basal layers provide shelter for a mature endolithic community dominated by only two endoliths while the top layer of the dead crust seems to be infested by a juvenile community composed of a mixture of microborers. This suggests that the dead crusts were collected shortly after damage occurred. The absence of epilithic algae (only few filaments have been observed) and grazer scars confirm the recent death of the coralline.

\subsection{Boring patterns}

The difference in boring strategy and pattern is expressed by the opposite orientation of the boring network's density progression. In the basal layers, the filament density decreases upward. In the live crusts, the progression of the filaments follows the same direction as that of the coralline vertical growth, and extends up to 1 to $1.5 \mathrm{~mm}$ below the live cell layers. This suggests that the endolith species adjust their penetration performance to the accretion rate of the crust. A similar strategy was reported by Le Campion-Alsumard et al. (1995a) for endoliths in live corals. We note that both Ostreobium and Plectonema could penetrate deeply $(2.73 \mathrm{~mm})$ into the carbonate substrata in experimental blocks of corals left exposed to boring organisms for two years Chazottes et al. 1995. In live crusts, even if euendolithic species requiring high light intensity would successfully colonise the base of the substrata, they are rapidly buried and deprived of light by new skeletal carbonate. This is probably the reason why $M$. testarum, $H$. caespitosa and various chlorophyta were seldom observed within the live crusts. In the dead crusts, the boring community is denser near the surface and its density decreases rapidly downward until it reaches the light compensation depth for the participating species, which is about $0.5 \mathrm{~mm}$, close to Chazottes et al (1995) values for coral substrata ( $0.77 \mathrm{~mm}$ for Mastigocoleus assemblage in experimental blocks exposed for 1 year). The depth of penetration could be largely determined by the species composition rather than by the temporal pattern of bioerosion activity Chazottes et al, 1995) Odum and Odum (1955) and Le Campion-Alsumardet_al_(1995a deported similar trends for corals. Moreover, the basal layer in the dead crusts is less dense than in the live crusts since endoliths in the top layer and the epiliths on the surface crusts probably reduce the light available for the organisms in the basal layer Le Campion-Alsumard et al. 1995a; Gektidis. 1999.

The boring patterns could be in part controlled by the structural properties of the substratum. For instance, Ostreobium is unable to bore over organic lamellae Golubic et al. 1975. Regarding the internal structure of $H$. onkodes, we can assume that the abundance of organic matter in the upper living part of the thallus limits the penetration of Plectonema and Ostreobium up to the surface. That could explain the restriction of the species under the living part of the crust. Conversely, numerous large cell fusions in the medulla (basal part) of $H$. onkodes could promote the development of endoliths, explaining also why the Lithophyllidaea are less subject to infestation by endoliths (pers. obs.) since this subfamily does not show such cell-fusion.

With respect to the variation of $M$. testarum filament diameters observed between live and dead crusts, we 
suggest that the species morphometric characteristics may explain the apparent variability rather than the substratum properties.

\subsection{Microboring bioerosion significance}

The observed differences in species composition, filament diameters, distribution of endoliths and depth of penetration between live and dead crusts amount to significantly higher rates of bioerosion in the dead crust than in the live one. The estimated amount of carbonate removed from dead crusts is four times that of live crusts of similar thickness and age.

The estimate of the effect of bioerosion in live crusts reported in table $b$ is similar to those calculated from measurements of micro-porosity (L. Fallot, pers. commun., 2000). A difference of $9.3 \%$ in micro-porosity between the basal and the top layers of live Hydrolithon onkodes was reported. Considering the relative density of calcareous algae $\left(1.50 \mathrm{~g} \cdot \mathrm{cm}^{-3}\right)$, the removal of $\mathrm{CaCO}_{3}$ can be estimated to be $0.14 \mathrm{vs} .0 .12 \mathrm{~g} \cdot \mathrm{cm}^{-3}$ estimated by image analysis which is relatively similar and represents $7.9 \%$ of bored substratum. These findings are in contrast with the $25 \%$ found by Le Campion-Alsumard_et al 1995a in live heads of the coral Porites lobata. Conversely, for the dead substrata, our result (31.6\%) agrees with those of Chazottes et al_(1995) (from $22.4 \%$ for the initial infestation to $30.8 \%$ after 2 years of exposure). Moreover, Zubia and Peyrot-Clausade (2001) found between 19.6 to $30.8 \%$ of bored dead Acropora by endoliths on the reefs of La Reunion Island.

Few quantitative studies on internal bioerosion have treated separately the rates of boring by macroborers and microborers Kiene and Hutchings. 1994: Peyrot et al. 1995; Pariet al, 1998) because the treatment of the latter required special techniques such as these introduced by Chazottes et al (1995). According to this study, microendoliths are responsible for more than $50 \%$ of the total bioerosion recorded during the initial stages of bioerosion ( $\leq 1$ year of exposure). After 24 months of exposure, their contribution is only $10 \%$. Endoliths are direct agents of bioerosion by dissolving the carbonate substratum, and making it more susceptible to damage by physical events (cyclones, storms) since the bored layers represent zones of less resistance.

Nevertheless, endoliths are more important as indirect agents of bioerosion than direct agents since in the top layer they are a major food resource for grazers Lukas. 1979]. Within H. onkodes, the two communities of the top and basal layers do not have the same significance regarding organic production matter and bioerosion processes. Following the death of the alga providing the carbonate substratum, the subsequent development of boring endolithic community within the top green layer makes it a desirable food resource for many grazing organisms such as echinoids and scarids Bruggemann et Gl. 1994: Bellwood 1995: Chazottes. 1996: Pari et al. 1998. Peyrot-Clausade et al. 1999]. Indeed, scarids fish feed preferentially on substrata infested with endoliths rather than on substrata covered with live corallines Bruggemann et al.. 1996) Grazers stimulate the growth of endolithic algae and ensure a renewable food resource. Grazing also inhibits the settlement of epilithic macro- and microphytes, which compete with endoliths for substratum (Chazottes et al, 1995). Finally, these initial colonisers of newly available carbonate substrata may also facilitate subsequent recruitment by other borers (Hutchings et al, 1992; Chazottes et al, 1995). For instance, M. Peyrot-Clausade (pers. commun., 1998) found more polychaetes and sipunculans in dead crusts than in live ones.

Compared to the top layer, the importance of the basal layers is more speculative. As suggested by Qdum and Odum (1955) and Fork and Larkum (1989) endoliths in the basal layers in the live crusts could have a symbiotic relationship, or exchange of nutrients Delvove. 1992) with their hosts.

This present study has confirmed the presence of microborers in coralline skeleton of Hydrolithon onkodes and suggests a probable important role in the bioerosion processes. Knowing that coralline fragments can represent between 27 to $43 \%$ of the trapped sediments at Moorea (Peyrot-Clausade et_al,_1999), this preliminary study should be completed by a spatial and a temporal approach and extended to macroborers and grazers since these two compartments become the major agents of bioerosion over time.

\section{Acknowledgements}

This study is a part of a long-term research on coral reef bioerosion supported by the French National Programme on Coral Reefs (PNRCO) and the French National Programme on Coastal Environment (PNEC). We especially thank T. Le Campion-Alsumard for her valuable and very helpful remarks and for her contribution 
to our knowledge of endolithic microalgae. We also wish to thank the following persons for assistance in the statistical treatment of the data or in the field: Dr J. Le Campion, J. Algret, C. Bezac, J. Herbaut, and C. Marschal.

\section{REFERENCES}

Adey, W.H., 1998. Coral reefs: algal structured and mediated ecosystems in shallow, turbulent, alkaline waters. J. Phycol. 34, 393-406.

Anagnostidis, K., Pantazidou, A., 1988. Cyanosaccus atticus, a new marine euendolithic chroococcoid cyanophyte in relation to the epilithic Podocapsa Erceg. Arch. Hydrobiol. Suppl. Algol. Stud. 48, 279-302.

Augustin, D., Galzin, R., Legendre, P., Salvat, B., 1997. Variation interannuelle des peuplements récifaux du récif-barrière de Tiahura (île de Moorea, Polynésie française). Oceanol. Acta 20, 743-755.

Bellwood, D.R., 1995. Carbonate transport and within-reef patterns of bioerosion and sediment release by parrotfishes (family Scaridae) on the Great Barrier Reef. Mar. Ecol. Prog. Ser. 117, 127-136.

Bellwood, D.R., Choat, J.H., 1990. A functional analysis of grazing in parrotfishes (family Scaridae): the ecological implications. Environ. Biol. Fish. 28, 189-214.

Bornet, E., Flahault, C., 1889. Sur quelques plantes vivant dans le test calcaire des mollusques. Bull. Soc. Bot. Fr. 36, 174-177.

Borowitzka, M.A., 1983. Calcium carbonates deposition by reef algae: morphological and physiological aspects. In: Barnes, D.J. (Ed.), Perspectives on Coral Reefs. AIMS Contribution, 200, pp. 16-27.

Bruggemann, J.H., van Oppen, M.J.H., Breeman, A.M., 1994. Foraging by the stoplight parrotfish Sparisoma viride. I. Food selection in different, socially determined habitats. Mar. Ecol. Prog. Ser. 106, $41-55$.

Bruggemann, J.H., van Kessel, A.M., van Rooj, J.M., Breeman, A.M., 1996. Bioerosion and sediment ingestion by the Caribbean parrotfish Scarus vetula and Sparisoma viride: implications of size, feeding mode and habitat use. Mar. Ecol. Prog. Ser. 134, 59-71.

Chazottes, V., 1996. Étude expérimentale de la bioérosion et de la sédimentogénèse en milieu récifal: effets de l'eutrophication (Ile de La Réunion, Océan Indien). C.R. Acad. Sci. Paris 323, 787-794.

Chazottes, V., Le Campion-Alsumard, T., Peyrot-Clausade, M., 1995. Bioerosion rates on coral reefs: interactions between macroborers, microborers and grazers (Moorea, French Polynesia). Palaeogeogr. Palaeoclimatol. Palaeoecol. 113, 189-198.

Dagnelie, P., 1970. Quelques méthodes non paramétriques. In: Duculot, J., Gembloux, S.A. (Eds.), Théorie et méthodes statistiques. Applications agronomiques, vol. 2, pp. 377-395.

Delvoye, L., 1992. Endolithic algae in living stony corals: algal concentrations under influence of depth-dependent light conditions and coral tissue fluorescence in Agaricia agaricites (L.) and Meandrina meandrites (L.) (Scleractinia, Anthozoa). Stud. Nat. Hist. Caribbean Region 71, 24-41.

Fork, D.C., Larkum, A.D.W., 1989. Light harvesting in the green alga Ostreobium sp., a coral symbiont adapted to extreme shade. Mar. Biol. 103, 381-385.
Galzin, R., Pointier, J.P., 1985. Moorea island, Society Archipelago. In: Gabrié, et al. (Eds.), Proc. 5th Int. Coral Reef Congr. Antenne Museum-EPHE, Moorea, French Polynesia. 1, pp. 73-102.

Gattuso, J.P., Pichon, M., Delesalle, B., Franquignoulle, M., 1993. Community metabolism and air-sea $\mathrm{CO}_{2}$ fluxes in coral reef ecosystem (Moorea, French Polynesia). Mar. Ecol. Prog. Ser. 96, 259-267.

Gektidis, M., 1999. Development of microbial euendolithic communities: The influence of light and time. Bull. Geol. Soc. Denmark 45, 147-150.

Ghirardelli, L.A., 1998. An endolithic cyanophyte in the cell wall of calcareous algae. Bot. Mar. 41, 367-373.

Ghirardelli, L.A., Prats, M., 1996. Endophytic microorganisms in calcareous algae. Giorn. Bot. It. 130, 931-933.

Golubic, S., Schneider, J., 1979. Carbonate dissolution. In: Trudinger, P.A., Swaine, D.J. (Eds.), Biogeochemical Cycling of MineralForming Elements. Elsevier, Amsterdam, pp. 107-129.

Golubic, S., Brent, G., Le Campion-Alsumard, T., 1970. Scanning electronic microscopy of endolithic algae and fungi using a multipurpose casting embedding technique. Lethaia 3, 203-209.

Golubic, S., Perkins, R.D., Lukas, K.T., 1975. Borings microorganisms and microborings in carbonate substrates. In: Frey, R.W. (Ed.), The Study of Trace Fossils. Springer, New York, pp. 229-259.

Golubic, S., Friedmann, I., Schneider, J., 1981. The lithobiontic ecological niche, with special reference to micro-organisms. J. Sed. Petrol. 51, 475-478.

Hook, J.E., Golubic, S., 1993. Microbial shell destruction in deep-sea mussels, Florida Escarpment. P.S.Z.N.I. Mar. Ecol. 14, 81-89.

Hutchings, P.A., 1986. Biological destruction of coral reefs. A review. Coral Reefs 4, 239-252.

Hutchings, P.A., Kiene, W.E., Cunningham, R.B., Donelly, C., 1992. Spatial and temporal patterns of non-colonial boring organisms (polychaetes, sipunculans and bivalve molluscs) in Porites at Lizard Island, Great Barrier Reef. Coral Reefs 11, 23-32.

Keats, D.W., Groener, A., Chamberlain, Y.M., 1993. Cell sloughing in the littoral zone coralline alga, Spongites yendoi (Foslie) Chamberlain (Corallinales, Rhodophyta) abundant in shallow reef environments in Fiji. Phycologia 32, 143-150.

Kendrick, B.W., Risk, M.J., Bergman, K., 1982. Amphibious microborers; bioeroding fungi isolated from live corals. Bull. Mar. Sci. 32, 862-867.

Kiene, W.E., Hutchings, P.A., 1994. Bioerosion experiments at Lizard Island, Great Barrier Reef. Coral Reefs 13, 91-98.

Kiene, W.E., Radtke, G., Gektidis, M., Golubic, S., Vogel, K., 1995. Factors controlling the distribution of microborers in Bahamian reef environments. In: Schumacher, H., Kiene, W.E., Dullo, W.C. (Eds.), Factors Controlling Holocene Reef Growth: An Interdisciplinary Approach. Facies, 32, pp. 176-188.

Le Campion-Alsumard, T., 1979. Les cyanophycées endolithes marines. Systématique, ultrastructure, écologie et biodestruction. Oceanol. Acta 2, 143-156.

Le Campion-Alsumard, T., 1989. Les cyanophycées marines endolithes. Bull. Soc. Bot. Fr. 136, 99-112. 
Le Campion-Alsumard, T., Golubic, S., Hutchings, P.A., 1995a. Microbial endoliths in skeletons of live and dead corals: Porites lobata (Moorea, French Polynesia). Mar. Ecol. Prog. Ser. 117, 149-157.

Le Campion-Alsumard, T., Golubic, S., Priess, K., 1995b. Fungi in corals: symbiosis or disease? Interaction between polyps and fungi causes pearl-like skeleton biomineralization. Mar. Ecol. Prog. Ser. $117,137-147$.

Littler, M.M., Littler, D.S., 1995. Impact of CLOD pathogen on pacific coral reefs. Science 267, 1356-1360.

Lukas, K.J., 1974. Two species of the chlorophyte genus Ostreobium from skeletons of Atlantic and Caribbean reef corals. J. Phycol. 10, 331-335.

Lukas, K.J., 1979. The effect of marine microphytes on carbonate substrata. Scanning Electron Microsc. 2, 447-456.

Mao Che, L., Le Campion-Alsumard, T., Boury-Esnault, N., Payri, C., Golubic, S., Bezac, C., 1996. Biodegradation of shells of the black oyster, Pinctada margaritifera Var. Cumingii, by microborers and sponges of French Polynesia. Mar. Biol. 126, 509-519.

Neumann, A.C., 1966. Observations on coastal erosion in Bermuda and measurements of the boring rate of the sponge Cliona lampa. Limnol. Oceanogr. 11, 92-108.

Odum, H.T., Odum, E.P., 1955. Trophic structure and productivity of a windward coral reef community. Ecol. Monogr. 25, 291-320.

Pari, N., Peyrot-Clausade, M., Le Campion-Alsumard, T., Hutchings, P.A., Chazottes, V., Golubic, S., Le Campion, J., Fontaine, M.F., 1998. Bioerosion of experimental substrates on high islands and on atoll lagoons (French Polynesia) after two years of exposure. Mar. Ecol. Prog. Ser. 166, 119-130.

Payri, C.E., 1995. Production carbonatée de quelques algues calcifiées sur un récif corallien de Polynésie française. Bull. Soc. Geol. Fr., Carbonates Intertropicaux 166, 77-84.

Penrose, D., Woelkerling, W.J., 1992. A reappraisal of Hydrolithon (Corallinaceae, Rhodophyta) and its relationship to Spongites. Phycologia 31, 81-88.

Peyrot-Clausade, M., Hutchings, P.A., Richard, G., 1992. Temporal variations of macroborers in massive Porites lobata on Moorea, French Polynesia. Coral Reefs 11, 161-166.

Peyrot-Clausade, M., Le Campion-Alsumard, T., Hutchings, P.A., Le Campion, J., Payri, C.E., Fontaine, M.F., 1995. Initial bioerosion and bioaccretion on experimental substrates in high island and atoll lagoons (French Polynesia). Oceanol. Acta 18, 531-541.
Peyrot-Clausade, M., Chazottes, V., Pari, N., 1999. Bioerosion in the carbonate budget of two Indo-Pacific reefs: La Réunion (Indian Ocean) and Moorea (Pacific Ocean). Bull. Geol. Soc. Denmark 45, 151-155.

Priess, K., Le Campion-Alsumard, T., Golubic, S., Gadel, F., Thomassin, B., 2000. Fungi in corals: black bands and density-banding of Porites lutea and Porites lobata skeleton. Mar. Biol. 136, 19-27.

Radtke, G., Le Campion-Alsumard, T., Golubic, S., 1997. Microbial assemblages involved in tropical coastal bioerosion: an AtlanticPacific comparison. Proc. 8th Int. Coral Reef Symp. 2, 1825-1830.

Sammarco, P.W., Risk, M., 1990. Large-scale patterns in internal bioerosion of Porites: cross continental shelf trends on the Great Barrier Reef. Mar. Ecol. Prog. Ser. 59, 145-156.

Schneider, J., Le Campion-Alsumard, T., 1999. Construction and destruction of carbonates by marine and freshwater cyanobacteria. Eur. J. Phycol. 34, 417-426.

Schneider, J., Torunski, H., 1983. Biokarst on limestone coasts, morphogenesis and sediment production. Mar. Ecol. 4, 45-63.

Steneck, R.C., 1986. The ecology of coralline algal crusts: Convergent Patterns and Adaptative strategies. Ann. Rev. Ecol. Syst. 17, 273-303.

Vogel, K., Kiene, W.E., Gektidis, M., Radtke, G., 1996. Scientific results from investigation of microbial borers and bioerosion in reef environments. In: Reitner, J., Neuweiler, F., Gunkel, F. (Eds.), Global and Regional Controls on Biogenic Sedimentation. I: Reef Evolution, Göttinger Arb. Geol. Paläontol., pp. 139-143.

Weber van Bosse, A., 1932. Algues. Résultats scientifiques du voyage aux Indes Orientales Néerlandaises de LL. AA. RR. Le Prince et la Princesse Léeopold de Belgique. Mus. Roy. Hist. Natur. (Belgique) Mem. Hors. Ser. 6, 1-28.

Wiegert, R.G., 1962. The selection of an optimum quadrat size for sampling the standing crop of grasses and forbs. Ecology 43, $125-129$.

Wilkinson, C.R., 2000. Status of coral Reefs of the World: 2000. Global Coral Reef Monitoring Network and Australian Institute of Marine Science. Townsville, Australia.

Zar, J.H., 1984. Biostatistical analysis. Prentice and Hall, Englewood Cliffs, NY.

Zubia, M., Peyrot-Clausade, M., 2001. Internal bioerosion in Acropora formosa in Réunion (Indian Ocean): microborer and macroborer activities. Oceanol. Acta 24, 251-262. 